\title{
Artikel Review : Metode Popular SROI dan Aplikasinya di Kehidupan Nyata
}

Oleh : Arvin Winatha

Email : s130119032@student.ubaya.ac.id

\section{Metode Popular SROI dan Aplikasinya di Kehidupan Nyata}

SROI adalah pendekatan yang relative baru untuk menciptakan nilai yang diciptakan oleh aktivitas manusia (Jeremy Nicholls, 2017). SROI dibandingkan dengan pendekatan global arus utama untuk menghasilkan informasi standar yang menginformasikan keputusan alokasi sumberdaya, akuntansi keuangan secara umum, akuntansi keberlanjutan di sektor swasta dan analisis manfaat biaya di sektor publik

SROI adalah sebuah metode popular untuk mengevaluasi dampak organisasi terhadap masyarakat dan lingkungan (John Gargani, 2017). SROI telah membuat gebrakan dari alat untuk membangun kekayaan pribadi menjadi sebuah alat yang dapat memajukan kepentingan public.

Ada 2 kerangka kerja yang digunakan untuk metaevaluasi SROI sendiri. Pertama, dengan membandingkan manfaat dengan biaya secara sumatif. Kedua, dengan mengevaluasi biaya dan manfaat sesuai dengan seberapa banyak orang-orang berkontribusi yang dilakukan melalui beberapa kegiatan. (Brian \& Marra, 2017).

SROI dalam keseluruhan proses analisis-nya melibatkan rasio dan kisah (Varinder, Niraj, Shubham \& Neema, 2017). Kisah tentang bagaimana program SROI telah menciptakan nilainilai selama dan setelah intervensi, dan Rasio tentang seberapa banyak nilai sosial yang diciptakan dari investasi.

SROI adalah metric yang membandingkan biaya sosial yang dimonetisasi dari suatu program dengan manfaat sosial yang dimonetisasi untuk mencapai serangkaian hasil (Joseph, 2017).

Dalam kehidupan nyata, SROI ini telah dikenal dan diterapkan di berbagai daerah dan negara. Di Indonesia sendiri SROI ini juga telah diterapkan salah satunya di kota Surabaya. Pada tahun 2004, diadakan program daur ulang berbasis masyarakat untuk pertama kali nya dengan cara pengendalian limbah di Rungkut Lor, sebuah lingkungan berpenghasilan rendah yang dikenal sebagai "Kotak Ajaib Takakura". Pada tahun 2005, kampanye yang ramah lingkungan dimulai dengan serangkaian kompetisi lingkungan. Hal ini berhasil memotivasi kelompokkelompok perumahan untuk membersihkan lingkungan mereka dan mengurangi limbah dari sumber dengan melakukan pemisahan limbah dan kompos. Hal ini terlihat positif dimana antara tahun 2005-2008, Surabaya telah mengurangi limbah dari 1.500 menjadi 1.150 ton/hari. Dampak dari SROI ini bisa mendorong masyarakat untuk meningkatkan berbagai inovasi sosial seperti yang terlihat dalam "Festival Surabaya Hijau dan Bersih", dimana lingkungan menjadi 
lebih bersih dan masyarakat bisa melakukan penghematan lebih dalam biaya layanan kesehatan dan mengecilkan biaya untuk membeli sayur-sayuran (Pratono, Suyanto, Marciano \& Zurbrugg, 2017).

Kota Surabaya sendiri memang menarik bagi wisatawan asing, salah satunya seorang perwakilan kementrian Malaysia yang bernama Mary Wong Lai Lin. Surabaya sendiri mentata rapi beberapa lingkungan perkampungannya, itu terlihat dari sedikitnya sampah dan lingkungan yang jauh dari kata kumuh. Sekretaris Dinas Kebersihan dan Ruang Terbuka Hijau (DKRTH) Kota Surabaya mengatakan bahwa nantinya kampung-kampung di Surabaya akan memiliki ciri khas masing-masing yang dijadikan jujukan wisatawan asing dari berbagai negara. Selain itu, pemerintah juga akan melakukan aktivitas tertentu, seperti mengadakan Lomba Surabaya Smart City (SSC) dimana Pemkot Surabaya akan memberikan stimulant agar tiap kampung bisa mengembangkan lebih luas lagi potensinya. SROI ini diterapkan untuk memudahkan langkah Surabaya menjadi "SMART CITY" yang mewujudkan Smart Environment, Smart Energy, Smart water,air and land management serta Smart Waste Management. Dengan diterpkannya SROI di Surabaya ini bisa mendatangkan dampak baik, dimana akan menarik wisatawan-wisatawan asing untuk datang berkunjung sehingga akan menghasilkan keuntungan atau return yang dapat meningkatkan pemasukan-pemasukan dan menggerakan perekonomian Kota Surabaya.

Gerakan Indonesia Bersih dilakukan sejak usia dini di Surabaya. Surabaya membuat "Program Bus Surabaya"yang dimana tiket naiknya bukan dibeli menggunakan uang, namun dengan menukarkan sejumlah tertentu kemasan air mineral bekas. Program ini sejalan dengan metode SROI dimana akan meningkatkan kesadaran masyarakat dan berdampak terhadap berkurangnya peredaran sampah plastik di wilayah Kota Surabaya. Ide ini sangat kreatif tentunya dan peran aktif masyarakat menjad kunci keberhasilan program ini. Gerakan ini diklaim menjadi yang pertama dan satu-satunya di dunia. Peran metode SROI disini terlihat positif bagi daerah Surabaya dimana Kota Surabaya menjadi lingkungan yang bersih dan dari segi masyarakatnya, masyarakat menjadi lebih hemat pengeluaran dalam bidang transportasi, dan tingkat kesehatan masyarakat akan lebih baik.

Dari segi pembangunan, Metode SROI di Surabaya dilakukan dengan menerapkan pembangunan yang berbasis lingkungan.Di beberapa tempat, Para Petani sudah menerapkan pertanian berbasis lingkungan yang berhasil memajukan pertanian mereka dan meningkatkan kesuksesan para petani. Begitu juga dengan kehidupan nelayan dan petani garam Surabaya yang didorong Bu Risma untuk mengembangkan pola pikir berbasis lingkungan. Nelayan diminta untuk menjaga kelestarian kawasan mangrove sehingga akan mulai terasa dampak positifnya. Secara perlahan dengan mengelola mangrove dengan baik, hasil ikan menjadi luar biasa, mutu hidup para nelayan pun ikut meningkat.

Penerapan SROI di bidang Infrastruktur, terlihat dalam aktivitas Surabaya melakukan percepatan pembangunan ekonomi dengan mengadakan Proyek Gerbangkertosusilo ,yang dimana menemaptkan Surabaya sebagai titik sentral utama. Proyek Gerbangkertosusila ini tersebar hingga Gresik, Bangkalan, Mojokerto, Surabaya, Sidoarjo dan Lamongan. Surabaya menjadi hub untuk wilayah-wilayah sekitarnya terutama akses transportasi dengan kereta api regional serta pembangunan double track dan autonomous rail rapid transit (ART). Terdapat 
proyek-proyek yang secara khusus hanya di dalam Kota Surabaya. Misalnya pengembangan LRT (light rail transport), pembangunan kereta Bandara Juanda dan Jalan Tol Juanda. Dengan adanya program ini dan diperkuat dengan SROI, mendatangkan manfaat positif. Surabaya menjadi peran strategis dalam kemajuan kawasan lain, akses transportasi menjadi lebih mudah dan terkoneksi dari satu daerah ke daerah lain, hemat waktu dan tentunya masyarakat akan lebih berhemat.

Dengan program program di atas, Surabaya menlajutkan eksistensinya sebagai Smart City ini san banyak penghargaan yang diterima oleh Surabaya. Surabaya berhasil meraih penghargaan yang meliputi Smart Government, Smart Environment dan Smart Living. Surabaya berhasil mengalahkan 60 partisipan lain dari seluruh 33 provinsi yang ada di Indonesia.

Dari penjelasan dan penerapan SROI di kehidupan nyata ini, SROI memiliki kelebihan dan kekurangan. SROI menawarkan solusi potensial untuk masalah masalah (Brian \& Mita, 2017). SROI ini juga dapat menggantikan keterbasan dari pendekatan konvensional dengan menambahkan manfaat sosial atau ROI. SROI memonetisasi semua hasil sosial, lingkungan dan keuangan yang baik berwujud maupun tidak berwujud untuk setiap uang yang diinvestasikan dalam inisiatif kesejahteraan sosial dari suatu program melalui kombinasi Cost Benefit Analysis. SROI ini dapat membantu manajemen dan pelaksana program untuk mengevaluasi sendiri efisiensi dan dampak dari intervensi sosial. (Varinder, Niraj, Shubham \& Neema, 2017). SROI dapat berfungsi sebagai alat yang dapat digunakan oleh pemerintah, investor swasta, dan yayasan untuk membantu menetapkan prioritas pendanaan, dan mengevaluasi kinerjanya (Joseph, 2017). SROI pun bisa digunakan sebagai alat untuk mengeksplorasi manfaat sosial dan ekonomi dari kegiatan seni (Allesandro, Justine \& Emma, 2019).

Namun selain memiliki kelebihan SROI juga memiliki kekwhatiran dan kekurangan dalam penerapannya. Kekhawatiran yang tersisa tentang SROI adalah bahwa belum diketahui pasti apakah SROI bisa memberikan manfaat yang cukup pada program-programnya (Brian \& Mita, 2017). Kadang data keuangan SROI bisa tidak konsisten dengan narasi kualitatif, sehingga akan menimbulkan kekhawatiran atas efektivitas SROI dalam menangkap implikasi dari sosialitas komunitas pengguna bangunan (Kelly, James, Andrew \& Tim, 2016).

Selain itu menurut pandangan saya terdapat beberapa kekurangan SROI. SROI jika ada kesalahan dalam penerapannya akan mengarah pada ketidakseimbangan antara usaha/cost dan social return yang diharapkan. SROI membutuhkan dukungan dari banyak pihak jadi evaluasi dan hal sebagainya akan lebih memakan waktu yang lebih banyak. SROI memiliki kelemahan pada prinsipal yaitu dalam membandingkan rate of return antara 2 kelompok yang tidak bisa digolongkan ke dalam sejenis. 


\section{DAFTAR PUSTAKA}

\section{Bibliography}

Bosco, A., Schneider, J., \& Broome, E. (2019). The social value of the arts for care home residents in England: A Social Return on Investment (SROI) analysis of the Imagine Arts programme. Maturitas, 124, 15-24. doi:10.1016/j.maturitas.2019.02.005

Cordes, J. J. (2017). Using cost-benefit analysis and social return on investment to evaluate the impact of social enterprise: Promises, implementation, and limitations. Evaluation and Program Planning, 64, 98-104. doi:10.1016/j.evalprogplan.2016.11.008

Gambhir, V. K., Majmudar, N., Sodhani, S., \& Gupta, N. (2017). Social Return on Investment (SROI) for Hindustan Unilever's (HUL) CSR initiative on livelihoods (Prabhat). Procedia Computer Science, 122, 556-563. doi:10.1016/j.procs.2017.11.406

Gargani, J. (2017). The leap from ROI to SROI: Farther than expected? Evaluation and Program Planning, 64, 116-126. doi:10.1016/j.evalprogplan.2017.01.005

Nicholls, J. (2017). Social return on investment-Development and convergence. Evaluation and Program Planning, 64, 127-135. doi:10.1016/j.evalprogplan.2016.11.011

Pratono, A. H., Suyanto, Marciano, D., \& Zurbrugg, C. (2017). Social Return On Investment for Community-based Enterprise in Surabaya. The Hong Kong Journal of Social Work, 51 (1/2), 93114.

Watson, K. J., Evans, J., Karvonen, A., \& Whitley, T. (2016). Capturing the social value of buildings: The promise of Social Return on Investment (SROI). Building and Environment, 103, 289-301. doi:10.1016/j.buildenv.2016.04.007

Yates, T. B., \& Marra, M. (2017). Social Return On Investment (SROI): Problems, solutions ... and is SROI a good investment? Evaluation and Program Planning, 64, 136-144.

doi:10.1016/j.evalprogplan.2016.11.009 
